\title{
ROAD INVESTMENT DESIGN IN AREAS PROTECTED BY THE MONUMENTS CONSERVATOR
}

\author{
Artur JUSZCZYK ${ }^{1}$ \\ University of Zielona Gora, Zielona Góra, Poland
}

\begin{abstract}
Design works on road construction plans for areas protected by conservation require a proper preparation, especially in terms of formality, which has been described in this paper.

One has shown the various methods of conduct in the course of obtaining administrative decisions and related difficulties, which are dependent on the form of monument protection and the scope of the proposed building works.

One has also raised a question regarding the law on the subject. One has suggested the consolidation of existing regulations and introduced the likely new direction that is currently in preparation.
\end{abstract}

Keywords: Road works, design of roads, historic building, conservation protection, building permit

\section{INTRODUCTION}

Road investments constitute an essential element of maintaining and developing transport infrastructure. Very often in urban areas transportation system is the result of a location from the Middle Ages. In order to preserve the values of urban or rural systems, these areas are protected by conservator at different levels. All investment projects at still monuments protected by law, representing building structures, are a special case of building works, as evidenced by other publications [e. g. 2, 3, 4]. The existing articles treat the problem in a general

\footnotetext{
${ }^{1}$ Corresponding author: University of Zielona Gora, Faculty of Civil Engineering, Architectureand Environmental Engineering, Z. Szafrana st 1, 65-516 Zielona Góra, Poland, e-mail: arturjuszczyk@o2.pl, tel. +48683284784
} 
way, without industry division of construction plans. Carrying out construction projects, including road, on this type of area requires proper preparation, both in terms of formality [1], as well as logistics.

\section{CONSERVATOR'S PROTECTION AND ROAD INVESTMENTS}

In Poland, protection and conservation issues are regulated by a number of legal acts, the most important being the Law on the protection of monuments and care of monuments [5]. Depending on the form of the monument protection and the scope of the planned building works, road projects are subject to various administrative procedures with authorities of architectural and building administration and with the conservators.

Road works may be implemented in the following modes: notice of construction works (ZR) according to art. 29 of act the Building Law [6], the building permit (PB) in accordance with art. 33 of act the Building Law and the decision authorizing implementation of road investment (ZRID) under the act on special rules of preparation and implementation of investments regarding public roads [7]. All of the above procedures apply to proceedings before administrative bodies of architecture and building, at the same time, they define different ways of making arrangements with the provincial conservation officer.

Arrangements road investments with the provincial conservation officer depend on the form of still monument protection, which is located in the area dedicated to investment. The most commonly used legal methods of areas protection are entries in the register of monuments or determination of the protection object in the local plan of spatial development and other decisions in the field of spatial planning.

\subsection{Road investments in areas listed in monuments register}

Urban or rural complex system, as well as the environment of another monument property, may be subject to a strict form of protection and be listed in the register of monuments. These are mostly areas of city centres, which were created in places of former settlements. Conducting works on such premises, as well as in its immediate environment, in accordance with art. 36 of the act 1 item 1 of the Law on the protection of monuments, requires a permit to carry out these works, issued by the appropriate provincial conservator. This decision must be obtained before applying for a PB (art. 39 paragraph 1 [5]). In the case of implementation of road construction works in this area based on the ZR or ZRID the obligation to obtain a permit issued by a conservator does not stop, despite the lack of relevant records respectively in the Building Law and road 
special law. However, it follows directly from the law on monuments protection, which records state that all the works in the areas listed in the register of monuments require conservator's approval (art. 36 paragraph 1 item $1[5])$.

The effective order at the administrative proceedings for road investments in the areas listed in the register of monuments were presented in the form of ideogram (Fig.1).

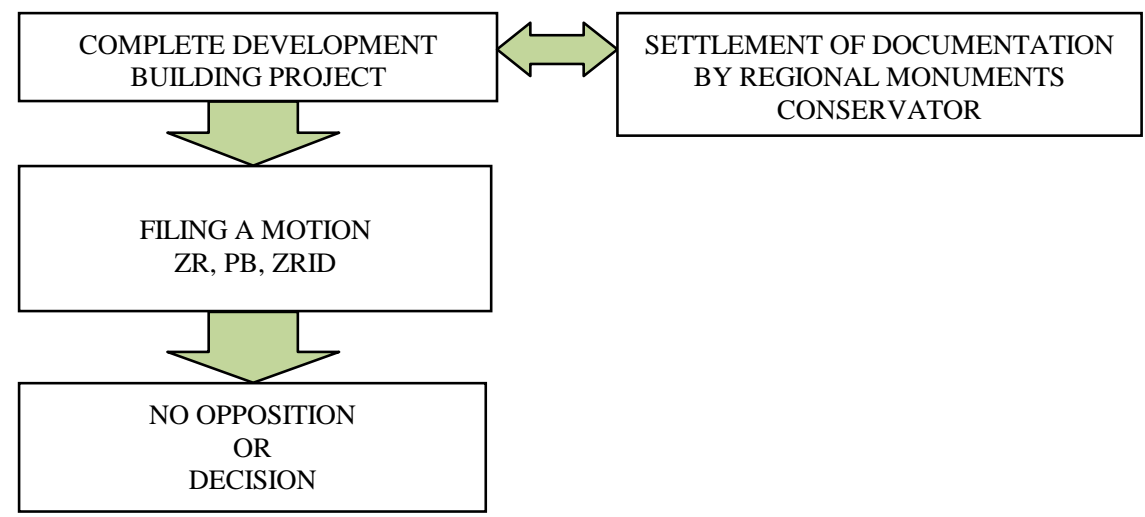

Fig. 1. Ideogram of procedure methodology for obtaining ZR, PB, ZRID for road investment in the areas listed in the register of monuments

\subsection{Road projects in the areas listed in the municipal register of monuments}

Areas included in the municipal register of monuments on the basis of local plan of spatial development are covered by a milder form of conservation protection. This usually applies to areas where the communication system or building form has been transformed as a result of previous actions.

For submissions of construction works in areas of special conservation protection, in legislation, there is no mandatory clarifications needed to make arrangements with the monuments conservator. In this situation, the body tasked to protect monuments has no insight into the project and, thus, is deprived of influence on design solutions.

The works, which require obtaining a building permit, are coordinated with the provincial conservation officer by the competent administrative authority of architecture and building on the stage of issuing this decision in accordance with art. 39 paragraph 3 of the Building Act. The course of the procedure for obtaining a building permit for the area included in the municipal register of monuments was presented in the form of ideogram (Fig. 2). It should be noted 
that this is the late time of the project preparation stage to make any optional changes of technical solutions.

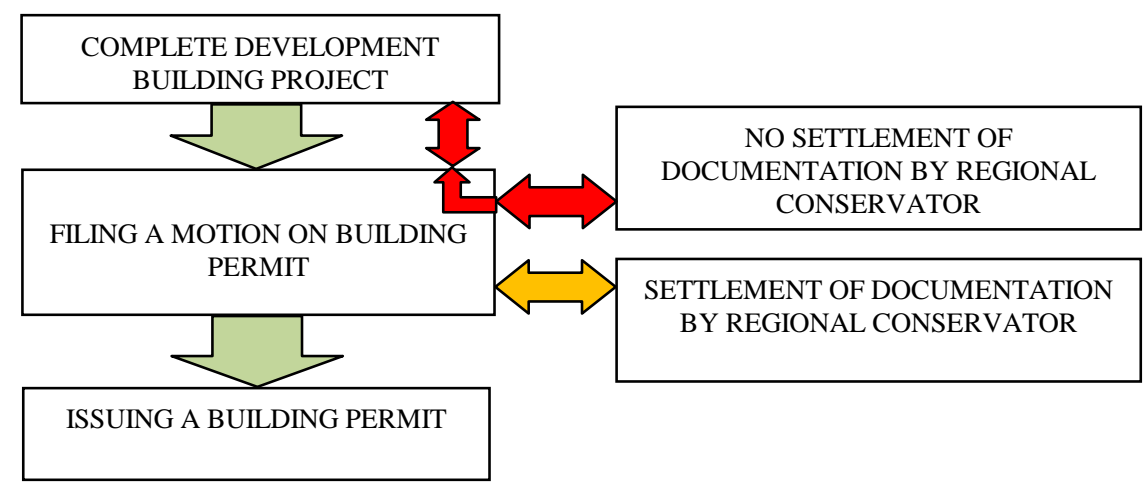

Fig. 2. Ideogram methodology procedure for obtaining a building permit in the areas listed in the municipal register of monuments

In respect of protected cultural property, which is planned expansion on, or construction of roads on the basis of the decision of ZRID, the competence of the provincial conservator has been reduced to issuing an opinion in accordance with art. 11d paragraph 8 point $f$ of road super act [7].

\section{DIFFICULTIES FOR ROAD INVESTMENT IN AREAS OF CONSERVATION PROTECTION}

Investments in the area under the protection of the conservator are difficult tasks, in terms of formal and technical conditions. When designing communications infrastructure extensive experience of the designer is necessary, not only in terms of building solutions, but also on legal issues. Knowledge of the design process, an appropriate sequence of paperwork reconciliation with the infrastructure managers and obtaining, required by different laws, decisions and opinions, is a key element in the project preparation stage.

The main difficulties in the preparation of road projects in the areas of conservation protection are:

- extension of the time needed to develop a complete construction project,

- the need for custom technical solutions,

- the need to perform additional field research.

Obtaining a permit or road arrangements of construction works with the monument conservator is an additional element that may significantly extend the time limit for preparation of project documentation. 
Conservator of monuments may impose specific requirements in areas such as: materials, qualifications of persons performing independent technical functions in the construction industry and the need to perform additional work, e. g. archaeological ones. The designer is the person who should provide appropriate technical solutions suitable to local conditions, with due justification. The use of old materials can have a negative impact on traffic conditions and road safety.

Excavation works, depending on their scope, are carried out during the construction period (just prior to the essential building works) or in advance. The importance, in this case, also has the location of the investment. The example of conducting archaeological works well in advance and rescue research during the implementation of the essential investments are shown in the photographs (fig. 3 and 4).

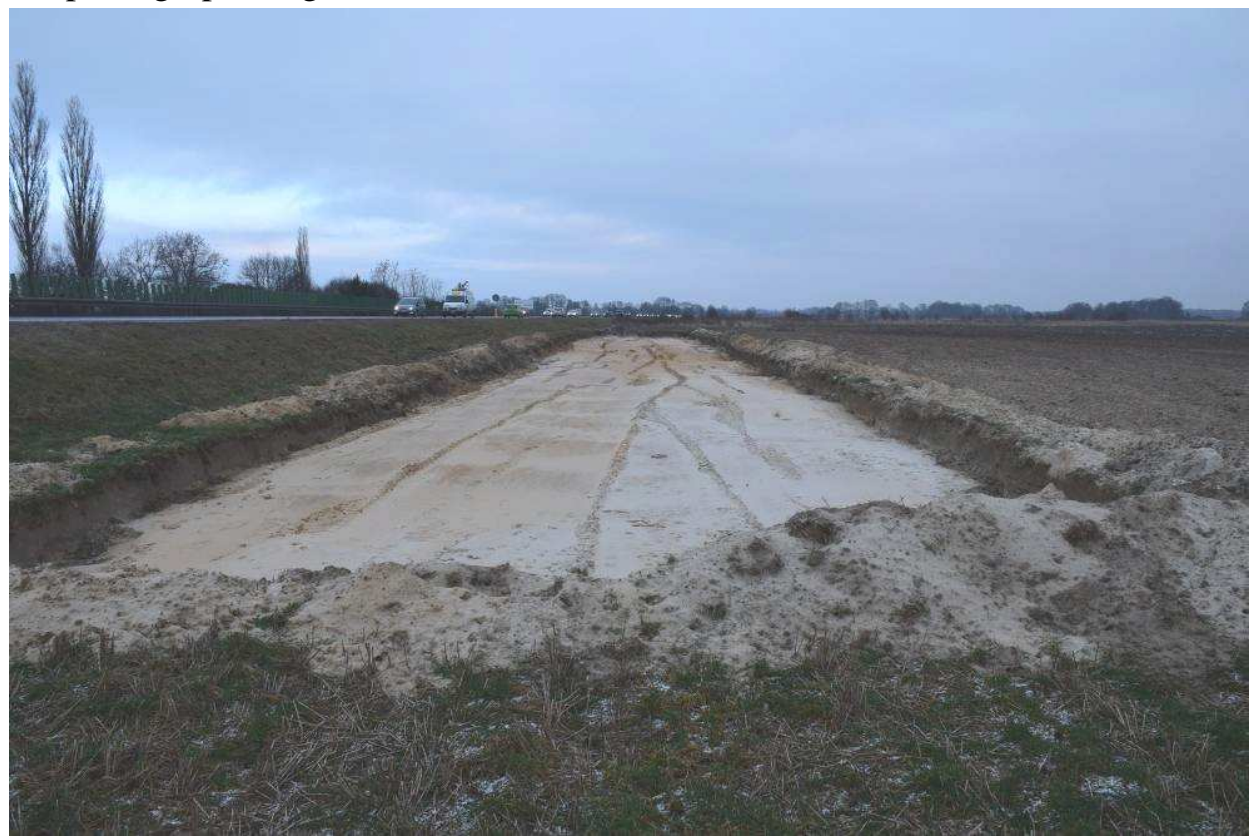

Fig. 3. View of the archaeological site at the stage of preparing the road construction

Obligation to carry out excavations of archaeological work is a significant impediment to the implementation of road investment, as it requires additional financial resources and time. It is one of the forms of protection of the cultural heritage of the past centuries. The alternative to such work is the use of technical solutions allowing leaving "monuments" intact at the current location. 


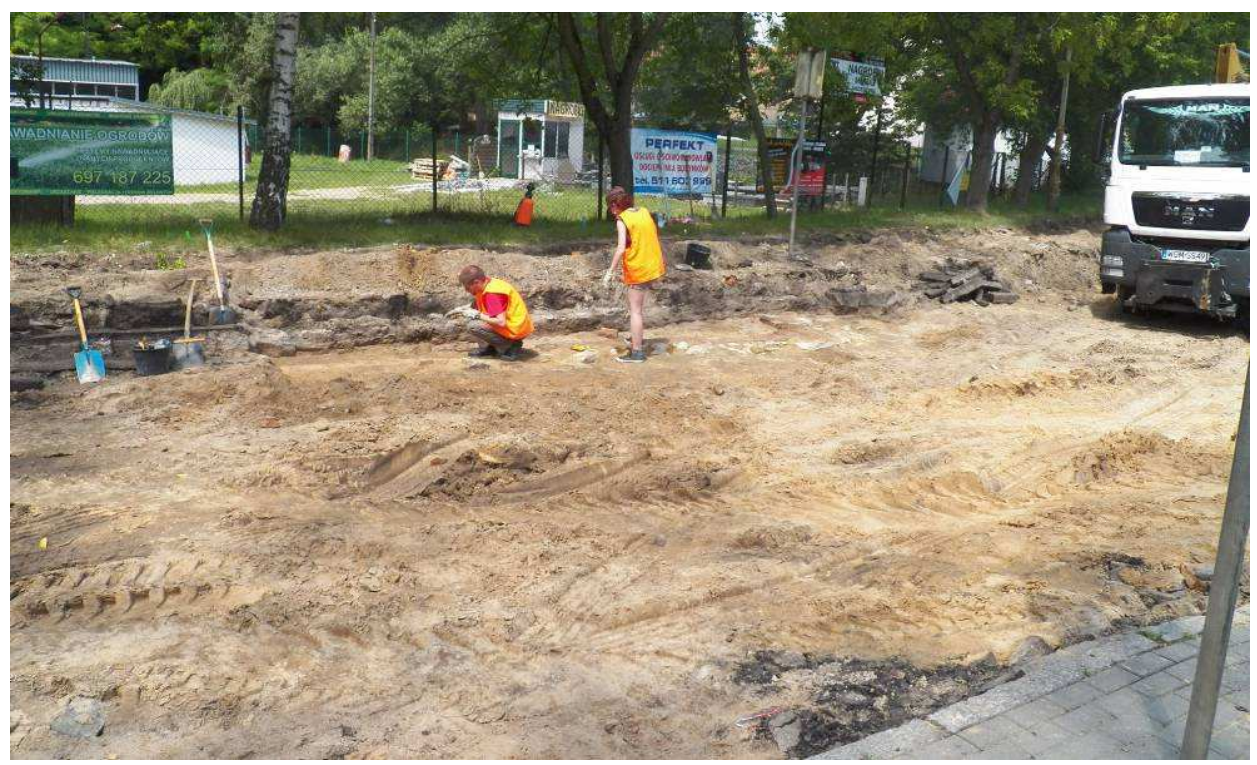

Fig. 4. View of conducting emergency research during the road investment

\section{CHANGES TO EFFECTIVE LAW}

The current legal status in the field of transport investments in areas under conservation protection require changes to improve the effectiveness of the conservator and to simplify administrative procedures. According to the author, the application of the methodology shown in figure 1 for all areas of protected monuments, will consolidate the conduct of investors' (developers') proceedings and will allow, in many cases, to shorten the period needed for the design works. In addition, one should also consider introduction of requiring the consent of the works scope implemented under the ZR. This will allow for better control of the protected area based on an entry in the municipal register of monuments by the monument conservator.

Urban planning and building code [8], proposes to increase control, of the provincial conservator and the Monuments General Conservator, over monuments listed in the register of monuments, for which it will be authorities of architectural and building administration. The new rules do not regulate the procedure for investments in protected areas on the basis of an entry in the municipal register of monuments, leaving them outside the competence of the conservator. A separate issue is the proposed extension of the scope of responsibilities exercised by institutions of monuments protection, which currently are not authorities of architectural and building administration. 


\section{CONCLUSIONS}

The coordination of road technical documentation with the conservator is an important element in the design process. Co-action of the designer and the investor with the conservator should be conducted from the beginning of the preparatory work. The decisions often impact on the time of the investment preparation and its timely implementation. This is particularly important because of the sources of financing and associated conditions of the funds use. Therefore, one should consider the possibility of issuing preliminary recommendations and guidelines prior to the start of design works. Subsequent administrative decisions of the conservator could be issued within a shorter period, as work on them would be largely based on checking the scope of the investment and the correctness of the implemented solutions.

For efficient road investment conduction in the area covered by the protection of the conservator it is crucial to have the knowledge of the scope and form of area protection. These are the key information affecting the easier and faster preparation of building works documentation. At present, with no major problems, we will find on the internet information about areas of nature protection. For example, we find, among others: maps with the area of protected site, basic information about the purpose of protection and its scope. Similar facilities should be introduced in relation to historic areas.

Changes in the law are an inevitable matter. Despite repeated changes to the Construction Law, one did not corrected thread on the execution of construction works in areas protected by the monument conservator.

Legislative works still continue regarding the final shape of urban planning and construction code and its finalisation is unknown, as well as its validity commencement. The current records of the Code on the subject of the paper mainly introduce administrative changes and at the same time they reduce the impact of the conservator for areas not listed in the register of monuments.

\section{REFERENCES}

1. Biliński T., Kucharczyk E.: Prawo budowlane, Zielona Góra, Oficyna Wydawnicza Uniwersytetu Zielonogórskiego, 2013.

2. Golat R.: Nowe uwarunkowania robót budowlanych przy zabytkach, Budownictwo i Prawo, R. 7, 5 (2003) 33-35.

3. Smarż J.: Zasady prowadzenia robót budowlanych $w$ obiektach wpisanych do rejestru zabytków, Budownictwo i Prawo, R. 16, 2 (2013) 3-7.

4. Sekunda R., Tischner L.: Projektowanie robót budowlanych $w$ obiektach zabytkowych, Przegląd Budowlany, R. 76, 5 (2005) 40-43. 
5. Ustawa z dnia 23 lipca 2003 r. o ochronie zabytków i opiece nad zabytkami (Dz. U. z 2014 r. nr 0 poz. 1446).

6. Ustawa z dnia 7 lipca 1994 r. Prawo budowlane (Dz. U. z 2013 r. nr 0 poz. 1409 z późniejszymi zmianami).

7. Ustawa z dnia 10 kwietnia 2003 r. o szczególnych zasadach przygotowania i realizacji inwestycji w zakresie dróg publicznych (Dz. U. z 2013 r. nr 0 poz. 687 z późniejszymi zmianami).

8. Projekt (wersja podstawowa) Kodeksu urbanistyczno-budowlanego przyjęty przez Komisję Kodyfikacyjną Prawa Budowlanego 16 kwietnia 2014 r. [online]. [dostęp: 11.11.2014]. Dostępny w internecie: www.mir.gov.pl/Budownictwo/Komisja_Kodyfikacyjna_Prawa_Budowlane go/Documents/Kodeks_urbanistyczno_budowlany_projekt_podstawowa_16 _04_2014_jednolity.pdf

\section{PROJEKTOWANIE INWESTYCJI DROGOWYCH NA OBSZARACH OBJĘTYCH OCHRONĄ KONSERWATORA ZABYTKÓW}

\section{Streszczenie}

Inwestycje drogowe stanowią niezbędny element utrzymania oraz rozwoju infrastruktury komunikacyjnej. Prace projektowe dotyczące drogowych zamierzeń budowlanych na obszarach objętych ochroną konserwatorską, wymagają należytego przygotowania szczególnie pod względem formalnym. Przedstawiono różne metodyki postępowania w toku uzyskiwania decyzji administracyjnych oraz związanych z nimi trudności, które to są uzależnione od formy ochrony zabytku oraz zakresu planowanych robót budowlanych. Poruszona została również kwestia dotycząca prawa w przedmiotowym zakresie. Zaproponowano ujednolicenie dotychczasowych przepisów oraz przedstawiono prawdopodobny kierunek nowych będących obecnie $w$ fazie przygotowań.

Słowa kluczowe: drogowe roboty budowlane, projektowanie dróg, obiekt zabytkowy, ochrona konserwatorska, pozwolenie na budowę 